\title{
Gilders and painters-gilders in the Golden Age of Évora
}

\author{
Antónia Fialho Conde $1,2,3, *$ \\ Custódia Araújo ${ }^{1,4}$ \\ Milene Gil ${ }^{1}$ \\ ${ }^{1}$ Hercules Laboratory, University of Évora, Évora, Portugal \\ ${ }^{2}$ CIDEHUS Centre, University of Évora, Évora, Portugal \\ ${ }^{3}$ Department of History of the University of Évora, Évora, Portugal \\ ${ }^{4}$ CHAIA Centre, University of Évora, Évora, Portugal \\ *antoniaconde@gmail.com
}

\begin{abstract}
At the end of the 15th century, Évora was a cosmopolitan town whose importance was increasing in cultural and artistic terms. Throughout the 16th century, and until the first half of 17th century, the town experienced a golden age, welcoming many Portuguese and foreign artists, who were closely following the royal court. Among them there were painters, gilders and woodcarvers, responding to the growing demand for work. This paper provides an insight into the lives of some of these men from the 16th to the early 18 th century. Through a documental survey, details of the gilded production, patrons and labor organization are presented, along with data on the personal and social daily life of these artists.
\end{abstract}

\section{Douradores e pintores no período áureo da cidade de Évora}

\section{Resumo}

Em finais do século XV, Évora era uma cidade cosmopolita com crescente importância em termos culturais e artísticos. Ao longo do século XVI e da primeira metade do século XVII, a cidade atravessou uma era dourada, acolhendo artistas portugueses e estrangeiros que procuravam estar próximos da Corte. Entre eles, constavam pintores, douradores e entalhadores, que atendiam à crescente demanda de trabalho. $O$ presente artigo oferece uma visão das vidas destes homens que trabalharam em Évora e no seu termo, ao longo do século XVI, até ao início do século XVIII. Com base em pesquisa documental, são apresentados detalhes das comissões, dos encomendantes e da organização laboral, assim como dados referentes à vida pessoal e social destes artistas.

\section{Keywords}

Gilders

Painters

Painters-gilders

Évora

Golden Period

Social History

\section{Palavras-chave}

Douradores

Pintores

Pintores-douradores

Évora

Período áureo

História social 


\section{Introduction}

The turn of the 15th to the 16th century left deep marks in Évora's urban life. Being the second largest town in the kingdom, cosmopolitan, the seat of the royal court and a witness to the diaspora of the Age of Discovery, it found new strengths in its inland location, as well as a new status among Portuguese towns. Politics, diplomacy and urban design witnessed that liveliness, together with culture and the arts. The charter issued by King Manuel in 1501 proves the energy of trade and consumption, driven by imported products seen as luxury items (marçaria items, spices, dyed and refined fabrics, delicate and precious stones), which are $37 \%$ of the items mentioned in the Évora charter, against the 30\% listed in the Lisbon or Santarém charters. There are also references to high-quality construction materials (e.g. in Lisbon and Santarém), like the Levante marbles.

As the kingdom's administrative seat in the Age of Discovery, Évora gave the instructions for the preparation of the India armada, of the Mina armada, of the "arrangements for the Flanders armada" and for the organization of some armadas against corsairs. As a political and administrative centre, it witnessed, for example, the establishment of the Inquisition or the appointment of diplomats to discuss the issue of the Moluccas with Castille. But it was in the period between 1520 and the 1560s-70s that Évora stood out as an artistic and cultural centre, with the creation of the University and the presence of several intellectuals and artists from different areas, together with seven printing houses and fifteen booksellers. The kings settled with the court in Évora several times, and were followed by a number of artists who were close to them, among them painters, sculptors and gilders. The court's presence in the town was more frequent during the 16th century (with King Manuel I, King John III, Cardinal D. Henrique, King Sebastian and King Phillip I). In the 17th century, only King Phillip II and King John IV stayed in the town, and in the following century only King John V spent some time there (in 1729). The Crown's presence became less and less significant, causing the increasing peripherization of the town and of its status as a political and diplomatic center and, above all, as an attractive town for artists, something that, naturally, had an impact in terms of artistic campaigns.

The present research focuses on a survey of records regarding gilders, painters-gilders and woodcarvers from the period in which the town of Évora was thriving - its so-called golden age - as a result of the aforementioned circumstances. In those days, people were passionately devoted. There were commissions for extremely precious pieces intended for temple decoration. Faith was expressed through the construction of magnificent altarpieces, paintings and jewellery. In this context, gilders and painters were highly sought after but little is known about these men and the commissions that they undertook in the town and its surroundings. Our goal was to complement the information that has already been published by obtaining new data about the artists' lives, patrons and commissions through different types of documents that remain understudied, such as notary records, parish records, wills and the so-called de genere inquiries.

\section{Patrons and gilding commissions in Évora - an overview}

\section{Commissions from convents and monasteries}

In the 16th century, in the Cistercian Monastery of São Bento de Cástris, the painter Diogo de Contreiras created an addendum to the initial contract concluded with the monastery's abbess and owners to "gild the white sections of the aforementioned Altarpiece" [1, 2]. Additionally, in the monastery's Visitation Book from 1790, there are plans to use a gilded coating to avoid corrosion, i.e., as a precautionary measure:

and considering also that our obligation is to avoid any possible damages and losses, and knowing that these may occur in the two altarpieces of our Patriarch's Altars, which are still made of corrodible wood, our instructions are to gild the aforementioned Altars as soon as possible to avoid that situation [3].

There are also documents from that period that mention painting and gilding works carried out in the monastery's church and in the chapel of São João Evangelista.

On the other hand, in April 1592, the nuns of the Convent of Santa Clara hired the painter Francisco João to paint and gild the altarpiece of the church's main altar within a period of three months [4-6]. He continued to work for the Poor Clares of Évora (there were three convents of Poor Clares in the town), this time for the nuns of Calvário - who by then obeyed the first Rule by painting and gilding the church's altarpiece in 1594, a work paid by Princess D. Maria [5-7]. The Convent of Salvador also obeyed the same Rule and, in 1626, its abbess - Sister Serafina do Salvador -, together with the nuns, hired the painters Pedro Nunes and António Vogado "to properly paint, gild and estofar the Altarpiece of the Church of Salvador". António Vogado was responsible for gilding the altarpiece while Pedro Nunes was responsible for the painting works, which should be perfectly finished using good quality paints [8-11].

The term estofar was (and still is) a gilding technique on which the metal foils are over painted and then carefully scratched to unveil the gilding underneath.

In the convent of São Francisco, before the Baroque and Rococo gilded woodcarving campaigns, there are references to the works carried out by Olivier de Gand (who was in Portugal between 1498 and 1512); these involved the Choir's chairs and the chancel's altarpiece, which he reassembled after gilding and painting its 
various parts [12-15]. Regarding the Convent of Cartuxa, there are also records from the 16th century, specifically from 1590, that mention the payment of services to the painter Manuel de Araújo, who should "pare and gild a number of Images kept in Cartuxa" [16].

\section{Private commissions}

Another woodcarver who worked in Évora during the 16 th century, namely in 1546, was Pero de Frias; he was responsible for the woodcarvings of two altarpieces, commissioned by the Count of Prado and painted by António Nogueira, for the Church of Santo Estêvão de Beringel. In addition to the description of the scenes depicted in the altarpieces, the documents reveal interesting and thorough technical details [17-19]:

the Altarpieces' paneling shall be painted in a delicate blue, while the tops and flowers shall be gilded, as well as the moldings and pillars [...], and all the painting works shall be carried out using the finest paints, and the gilding works using fine gold, and all this shall be made and finished as mentioned above by António Nogueira until January next year, fifteen hundred forty-seven.

\section{Woodcarvings in the Évora Cathedral}

The expenditures made in 1588 , when D. Teotónio de Bragança was in charge, include costs that we may consider as being related to the notion of heritage conservation of that time: "four sponges to clean and wash the Altarpieces' panels and two fox tails to brush off the golden dust of the Altarpieces" [20].

With regard to the Évora Cathedral, Archbishop D. José de Melo (1611-1633) ordered the payment of 60,000 réis to Diogo and António Vogado, Manuel Fernandes and Bartolomeu Sanches in 1624, so they could gild the tabernacle and the altarpiece of the Chapel of Santíssimo Sacramento [21]. Four years later, in 1629, through his representatives - the Graduate Luís de Azambuja de Moura and Father Luís Pires - the Archbishop chose a very similar team - Manuel Fernandes, Diogo Vogado, António Vogado and Pedro Nunes, "painters and gilders from this town" - to paint, gild, apply skin tones, estofar and adorn the grand woodcarved Sepulcher located in the Cathedral's chancel for the exceptional amount of 600,000 réis $[10,11,22,23]$.

Throughout the 17th century there were several interventions in the Évora Cathedral. In 1608, the Chapter ordered the altarpiece of the Chapel of Santo Sacramento [24] to be repaired and re-gilded and, in 1660, there were instructions to gild the Tabernacle's lock [25, fol.34v.] and a thurible [25, fol.39v.]; in 1681, the Chapter concluded a contract with Francisco Lopes Mendes, who should paint and gild one of the sacristy paintings [26]; in 1687, João do Touro was paid 200,000 réis to gild the extension of the Cathedral's Sepulcher [27] and, in the following year, the same artist gilded the frontal of the same Sepulcher [28].
At the turn of the 17th century, Archbishop D. Luis da Silva Teles (1691-1703) became responsible for the works that had begun in the Cathedral during the Vacant Seat (1698-1691), ordering the completion of the woodcarved altarpieces of the nine chapels located along the church's body, which were already underway, and instructing the woodcarver to finish the works according to the design that had been approved by the Chapter. After the woodcarvings were completed,

he ordered the altarpieces to be gilded and their panels to be cleaned, and some of them retouched, and in this work he spent $892 \$ 000$ réis; and this is how those beautiful chapels were finished, with their gilded altarpieces, their clean panels, and their painted ceilings, and now we can celebrate Mass there, something we didn't do before that $[29,30]$.

D. Frei Luís da Silva Teles was the 10th Archbishop of Évora, between 1691 and 1703 [31, 32]. In addition to being focused on educating the congregation (namely by promoting the printing of catechisms) and helping the poor, we should highlight his extraordinary patronage in the construction and decoration of the town's churches and altars (which implied hiring several artists), and near the city, like in Montemor-o-Novo. He also purchased vestments and implements, namely for the Church of São Pedro, the sacristy of Carmo, the Chapel of São Sebastião and the altarpiece of Santo Antão.

In 1724, João Frederico Ludovice supervised the works carried out in the chancel of the Évora Cathedral, which were aimed at giving it the look it currently has, informing that

with regard to what was part of the building's ceiling or first vault, His Majesty was of the opinion that what was gilded in the model should be made in white marble with blue shades, like those of the Sintra blue marble, or like a kind of Montes Claros marble, without any white spots or grids [33].

In 1725, from Lisbon, Ludovice stated he had written a letter to Manuel da Cruz explaining him how he should deal with the chancel ceiling in order to "renovate the gilded ceiling using stone so it would match the building's style" [34], and also giving him technical instructions on how to anchor the stone.

In 1746, the Fabric of the Évora Cathedral's made further payments to the carpenters who were working in the Chapel of Santíssimo Sacramento so they could build the scaffold to gild it [35] and, two years later, in 1748, there was a significant amount spent with the purchase of gold to gild the Chapel of Santo Lenho, with the gilders who applied it, with the paints and with the extension of chapel's tabernacle [36].

In 1749, the Cathedral's fabric commission purchased six pounds gold from the painter Manuel Coelho Galvão to gild the credenzas in the chancel [37]. There were more expenses related to this area in the following decade, namely in 1755 , which included payments to carpenters, 
woodcarvers and gilders [38]; in 1760, there is a reference to the gilding of the organ in the Cathedral's chancel [39]. In the last quarter of the century, specifically in 1777 , the Cathedral's fabric commission paid for expenses related to the gilding and painting of the oratory in the high choir [40].

\section{The brotherhoods and the Misericórdias from the town and its outskirts}

In 1603, with regard to the church of Vila Nova da Baronia (approximately $30 \mathrm{~km}$ away from Évora), the painter José de Escovar had agreed with the Almas Brotherhood that he would paint the wood panels of the altarpiece, gild the woodcarvings and estofar the processional image. The undertaking implied also that the chapel arch and walls should be painted with frescoes and in order for the works to be finished it was only necessary to gild the altarpiece's moldings and bench, as well as half the chapel; there was also an image that needed to be gilded and estofada $[6,10,41]$. The same artist agreed, with the ombudsman and the brothers of the Misericórdia of Mora, that he would paint, gild and estofar the main altarpiece of the Church of Misericórdia [10, 42-44]. It must be noted that, currently, José de Escovar is mainly known as a mural painter but these documents show that he was a proficient artist in other art forms as well.

In 1610, the painter Manuel Fernandes concluded a similar contract with the Menino Jesus Brotherhood, based in the Convent of Santa Mónica in Évora, for the altarpiece of the Brotherhood's chapel [10, 45, 46]. The same painter, in the same year and with the same notary Manuel Fernandes -, concluded yet another contract with the majordomos of the São Crispim e São Crispiniano Brotherhood (the brotherhood of Évora's shoemakers, whose altar was located in the Church of Santo Antão) to gild and estofar its chapel's altarpiece [10, 46, 47]. In 1617, the same painter undertook the same tasks in the altarpiece of the Chapel of Nome de Jesus, also located in the Church of Santo Antão, but owned by the silk weavers brotherhood [10, 48]. In 1621, the painters and gilders Manuel Fernandes and Bartolomeu Sanchez agreed with the majordomos of the Nossa Senhora da Conceição Brotherhood, based in the Convent of São Francisco of Évora, that they would gild and estofar the Brotherhood's altarpiece [10, 49].

\section{College of the Society of Jesus - University of Évora}

In 1689, a painting that depicted Our Lady was transferred from the small chapel to the large chapel of the noviciate of the Society College; at this time, a new altarpiece was made, as well as new paintings, and the ceiling was decorated $[50,51]$. There are also documents that mention the construction of altarpieces commissioned by Father Bento de Lemos for the Valbom Estate, a retreat for the Company's priests:

There were orders to begin with the holiest tasks, which are building and gilding the three altarpieces of the Valbom Estate's altars: they are new, rich, beautiful and magnificent woodcarvings $[50$, fls. 509,510 v.].

\section{Gilding and painting activities in other churches and chapels in the town and under the archbishopric}

In 1570, the painter José de Escovar became again responsible for gilding and estofar the main altarpiece of the Mother Church of Viana do Alentejo, by order of the archbishopric; for 30,000 réis, he should gild the columns, the tabernacle, the woodcarvings and the moldings of the existing panels [10, 52]; in 1619, Escovar also left his mark in terms of ephemeral architecture by participating in the town's festivities with "gilded decorations that shall adorn flags hoisted on poles with His Majesty King Filipe II of Portugal's coat of arms after the birth of the crown prince" $[10,53]$.

In 1588, the Chapter ordered the chancel of the Church of Redondo to be adorned, providing specific instructions for it to be decorated "up to the cymatium using scraped black and gild woodcarving(?)" [54]. A few years later, in 1569, the Chapter of Évora was again involved in the payment of (one third of) the painting and gilding expenses related to the Church of Redondo's tabernacle [55].

In the town's churches, and in chronological order, we know that, in 1597 and 1598, there was a new altarpiece in the Church of São Vicente (known as São Vicente das Irmãs) that was yet to be painted and gilded [56]. In 1591, the Chapter of Évora paid the painters who gilded the altarpiece of the Church of Santo Antão [57].

In 1659, the Cathedral's Chapter suggested that the altarpiece of the Church of Monsaraz should be gilded and subject to the necessary repair works, stating also that this work should be carried out by the gilder Manuel Fernandes [58]. In 1748-79 there are records of expenses made by the Cathedral's fabric commission to pay for an altarpiece commissioned by Archbishop D. Friar Miguel de Távora for the chancel of the Mother Church of Evoramonte, which included the purchase of wood, nails, and the wages of carpenters and woodcarvers [59]. In 1763, the Évora Cathedral's fabric commission was responsible for the gilding of the altarpiece located in the chancel of the Church of São Pedro, built outside the walls of Evoramonte [60]. In 1763, the Chapter concluded a contract with the archdeacon of Lavre so that the master carpenter Garcia dos Mártires could carry out a series of works in the Mother Church of Lavre, the most important of which was the chancel's altarpiece [61]. 
Table 1

Gilders, painters-gilders and carpenters in Évora (16th-18th centuries)

\begin{tabular}{|c|c|c|c|c|}
\hline Name & Date & Town/town/ village & Place & Occupation \\
\hline Olivier de Gand & $15 \ldots$ & Évora & Convent of S. Francisco - choir chairs and altarpiece & Painter-gilder \\
\hline Diogo Contreiras & $1540 / 50$ & Évora & Monastery of S. Bento de Cástris - altarpiece & Painter-gilder \\
\hline Pero de Frias & 1546 & Beringel & Church of Santo Estêvão - 2 altarpieces & Gilder and woodcarver \\
\hline António Nogueira & 1546 & Beringel & Church of Santo Estêvão - 2 altarpieces & Painter \\
\hline José de Escovar & 1570 & Viana do Alentejo & Mother Church - altarpiece & Gilder and woodcarver \\
\hline Manuel de Araújo & 1590 & Évora & Cartuxa Convent & Painter \\
\hline \multirow[t]{2}{*}{ Francisco João } & 1592 & Évora & Convent of Santa Clara - altarpiece of the main altar & Painter-gilder \\
\hline & 1594 & Évora & Calvário Convent - altarpiece of the main altar & Painter-gilder \\
\hline \multirow[t]{2}{*}{ José de Escovar } & 1603 & $\begin{array}{l}\text { Vila Nova de } \\
\text { Baronia }\end{array}$ & Church of the Almas brotherhood - altarpiece & Painter-gilder \\
\hline & 1603 & Mora & Church of Misericórdia - altarpiece & Painter-gilder \\
\hline \multirow[t]{2}{*}{ Manuel Fernandes } & 1610 & Évora & $\begin{array}{l}\text { Convent of Santa Mónica - altarpiece of the Menino Jesus } \\
\text { brotherhood }\end{array}$ & Gilder and woodcarver \\
\hline & & & $\begin{array}{l}\text { Church of Santo Antão - altarpiece of the S. Crispim e S. } \\
\text { Crispiano brotherhood }\end{array}$ & Gilder and woodcarver \\
\hline Manuel Fernandes & 1617 & Évora & $\begin{array}{l}\text { Church of Santo Antão - altarpiece of the chapel of Nome } \\
\text { de Jesus, owned by the silk weavers brotherhood }\end{array}$ & Gilder and woodcarver \\
\hline $\begin{array}{l}\text { Manuel Fernandes and } \\
\text { Bartolomeu Sanches }\end{array}$ & 1621 & Évora & $\begin{array}{l}\text { Convent of S. Francisco - altarpiece of the Nossa Senhora } \\
\text { da Conceiçao brotherhood }\end{array}$ & Painters-gilders \\
\hline $\begin{array}{l}\text { Diogo and António Vogado, } \\
\text { Manuel Fernandes and } \\
\text { Bartolomeu Sanches }\end{array}$ & 1624 & Évora & $\begin{array}{l}\text { Cathedral - tabernacle and altarpiece of the Chapel of } \\
\text { Santíssimo Sacramento }\end{array}$ & Gilders \\
\hline $\begin{array}{l}\text { Manuel Fernandes, Diogo } \\
\text { Vogado, António Vogado } \\
\text { and Pedro Nunes }\end{array}$ & 1629 & Évora & Cathedral - sepulcher in the chancel & Painters-gilders \\
\hline António Vogado & 1626 & Évora & Convento of Salvador - altarpiece of the church & Gilder \\
\hline Pedro Nunes & 1626 & Évora & Convent of Salvador- altarpiece of the church & Painter \\
\hline Manuel Fernandes & 1659 & Monsaraz & Main Church - altarpiece & Gilder \\
\hline Francisco Lopes Mendes & 1681 & Évora & Cathedral - sacristy & Painter-gilder \\
\hline João do Touro & $1687-88$ & Évora & Cathedral - extension of the sepulcher & Gilder \\
\hline $\begin{array}{l}\text { Manuel da Cruz (under } \\
\text { Ludovice's supervision) }\end{array}$ & $1724-25$ & Évora & Cathedral - main chapel & Gilder \\
\hline Manuel Coelho Galvão & 1749 & Évora & Cathedral - main chapel's credenzas & Painter-gilder \\
\hline
\end{tabular}

\section{Gilders and painters-gilders}

\section{Labor organization}

Table 1 provides a summary list of gilders, painters and woodcarvers that are cited in the previous section. The joint reference to paintings and gilding techniques underlines a deep relation between the two artistic expressions and reveals that it was usually for painters to work closely with gilders or even to be referred as having both activities, the so-called painter-gilder. Painters were responsible for performing different types of tasks; although oil painting was seen as the most prestigious art form, most contracts included gilding and estofado works.

It was quite common for painters-gilders to come together for attending to the demands. Manuel Fernandes, a particularly prolific painter-gilder during the first half of the 17th century (fl.1612-1641), did it at least three times between 1621 and 1629 with colleagues such as the Spanish painter Bartolomeu Sanches and the Portuguese 
painters Custódio da Costa, Bartolomeu Costa, António Vogado, Diogo Vogado and Pedro Nunes (Table1). Pedro Nunes, who became one of the most renowned Mannerist painters, was an apprentice of Manuel Fernandes, who took him in at the age of sixteen for five years of apprenticeship and married him to his daughter Mariana Varela [62]. Many of the artists were related either by blood or by marriage. On April 30th 1629, when Archbishop José de Mello commissioned the paint, gild and estofado of the large Sepulcher of the Évora Cathedral's Main Chapel, for the outstanding amount of 600,000 réis, Pedro Nunes, aged 44, undertook the commission not only with his father-in-law but apparently also with his son-in-law António Vogado and his cofather-in-law Diogo Vogado [63].

Gilding commissions were mostly of religious nature and, as such, it was very important for these artists to show that they lived according to the principles of the Catholic Church. Many craftsmen are mentioned in de genere inquiries regarding their relatives. These inquiries were attempts to find out if their descendants were in any way connected to the Church and, often, to establish blood lines. For example, in the de genere inquiry of Bartolomeu Sanches' grandson (Valério de Madureira) in 1662-1663 [10], it is said that Bartolomeu was a very good man and a respected Christian; this document served also as proof of the irreproachable purity of blood of Bartolomeu Sanches' family. The Inquisition, established in Portugal in 1536, was not to be taken lightly. Several cases of accusations are lodged in the Court of the Holy Office in Évora, sometimes even among craftsmen. In 1609, Manuel Fernandes, a painter known to have connections with the Portuguese Inquisition, accused his colleague António de Moura of being a New Christian by his mother's side and of pronouncing the Jewish word Adonai three times to cure toothaches and other ailments [64]. The complaint was apparently considered unfounded but it is enough to give a glimpse of the atmosphere of fear that ruled in those days and of how fragile working relationships could also have been.

\section{Economic status of the painters-gilders}

As it was shown in the previous section, a gilder's earnings were quite variable and depended greatly on the crafts he had to complete. In the consulted documents, there are very few references to painters and gilders who were manifestly destitute, like Domingos do Couto. Little is known about this painter who lived in Évora and worked in his trade from the late 16th century. His poverty is attested by the fact that he was unable to pay the usual alms of 500 réis for his soul, thus being buried in an ordinary tomb of the Santa Casa da Misericórdia on January 14th 1617 [6]. In the opposite side, stands Manuel Fernandes, who enjoyed an income of 200,000 réis per year, allowing him to own, and leave to his children, houses on Ancha
Street, one of the most important commercial streets in the town of Évora [65].

In notary records, there are several references to transactions and litigations involving the lease of vineyards, properties and houses held by artists. The existence of a significant number of loan and debt statements proves that it was common for these traders to borrow money from other professionals or from relatives. In 1537, the gilder Atanásio Fernandes had leased a series of vineyards in Peramanca, owned by the Cathedral's Chapter [66]; two years earlier, Luís da Serra, another gilder, had also leased a vineyard in the same place from the same owner (probably the same property) [66, fl. 149 v.]. With regard to the 17 th century we also have some information: in 1624 there is a reference to the lease of a tent on Selaria Street that should be paid to the Cathedral's bachelors so they could celebrate a mass for the soul of Bishop Master Parvi; the tent was owned by the gilder Manuel Gomes and, before that, it had been in the hands of another gilder, João Fernandes [67]. In 1651, the gilder Manuel João had leased a series of houses owned by the Cathedral's Chapter [66, fl. 80]. On April 6th 1691, the master stonemason Amaro Luís and the woodcarver Francisco Machado, who lived in Évora, were witnesses to the lease agreement regarding the Oliveiras Estate, in Serpa, concluded between the Carmo fathers and Bento Dias [68].

\section{Final notes}

Besides providing information on the location and extension of the carpentry, woodcarving and gilding works that were carried out, on the commissioners' demands and on the acknowledgment of several techniques as ways to protect the existing heritage, the consulted documents allow us to have an idea about the intense work undertaken by these professionals in the town and archbishopric of Evora between the 16th and the early 18th centuries. Évora's golden age was the result of intense teamwork efforts; painters, gilders and woodcarvers came together to meet the demands, mainly from the Church, in a town whose energy was driven by the presence of the court, the royal family, nobles and religious orders.

\section{Acknowledgments}

The authors want to acknowledge Fundação para a Ciência e Tecnologia for its financial support (Post-doc grant SFRH/ BPD/63552/2009) through program QREN-POPH-typology 4.1., co-participated by the Social European Fund (FSE) and MCTES National Fund; Project PRIM'ART PTDC/CPCEAT/4769/2012, financed by national funds through the FCT/ MEC and co-financed by the European Regional Development Fund (ERDF) through the COMPETE - Competitiveness Factors Operational Program (CFOP); the District Archive of Évora and the Évora Public Library; Paulina Araújo (Senior 
Technician) and Célia Caeiro (Technician) from the District Archive of Évora.

\section{References}

1 Manuscript, Biblioteca Pública de Évora, Fundo do Mosteiro S. Bento de Cástris, $1 .^{\circ} 11$, docs. 8, 214; $1 .^{\circ} 13$, docs. 11, 12.

2 Caetano, J. O., 'O pintor Diogo de Contreiras e a sua actividade no Convento de S. Bento de Cástris', A Cidade de Évora 45-50(71-76) (1988-93) 73-94.

3 'Livro da feitoria', manuscript, Biblioteca Pública de Évora, Fundo S. Bento de Cástris, cód. CXXXII/1-16, fl. 49v.

4 'Notícias genealógicas', manuscript, particular archive of Barreto de Carvalho (Vilas Boas) family, 1. ${ }^{\circ}$ do Cartório de Francisco Lopes, fl. 8v.

5 Espanca, T., 'A obra do pintor Francico João', A Cidade de Évora 12-13(37-38) (1955-1956) 183-200.

6 Espanca, T., 'Notas sobre pintores em Évora nos séc.XVIXVII', A Cidade de Evora 5(13-14) (1947) 109-213.

7 'Notícias genealógicas', manuscript, particular archive of Barreto de Carvalho (Vilas Boas) family, Cartório de Manuel Simões, caderno I, fl.14v.

8 'Notas de Manuel Rodrigues', manuscript, Arquivo Distrital de Évora, 1..$^{\circ} 423$, fls. 27v-30.

9 'Notas de António Gomes de Mariz', manuscript, Arquivo Distrital de Évora, $1 .^{\circ} 496$, fls. 82-84v.

10 Serrão, V., 'A pintura proto-barroca em Portugal. 16121657. Os pintores e as suas obras,' vol. 2, PhD dissertation, University of Coimbra, Coimbra (1992).

11 Serrão, V., 'Pedro Nunes (1586-1637). Um notável pintor maneirista eborense', A Cidade de Évora 45-50(71-76) (1988-93) 106-137.

12 Manuscript, Arquivo Nacional da Torre do Tombo, Corpo Chronologico, 2. ${ }^{\text {a }}$ parte, maço 17 , doc. 116.

13 Manuscript, Arquivo Nacional da Torre do Tombo, Corpo Chronologico, 1. ${ }^{\text {a }}$ parte, maço 6, doc. 7980.

14 Pereira, G., Documentos Históricos da Cidade de Éyora, $3^{\text {a }}$ parte, Tipografia Economica de José d'Oliveira, Évora (1891).

15 Moniz, M. C., Évora no Passado, vol. 1, Évora (1969).

16 'Inventario de tudo o que o Arcebispo tem dado aos Padres Cartuxos do Mosteiro de Scala Coeli d' esta Cidade de Evora, assi dinheiro, pam, como movel, e outras cousas ao diante declarados', manuscript, Biblioteca Pública de Évora, Évora, cód. CVII/1-28 (1588), fl.8 v.

17 'Notas de Diogo Luís', manuscript, Arquivo Distrital de Évora, Évora, 1. ${ }^{\circ} 12$, fls. 81-82v.

18 Caetano, J. O., 'O antigo retábulo de pintura da Capela-Mor da Igreja da Misericórdia de Beja', A Cidade de Evora 3940(65-66) (1982-83) 200-201.

19 Correia, V, Pintores Portugueses dos Séculos XV e XVI, Coimbra, (1928).

20 Manuscript, Biblioteca Pública de Évora, Évora, Fundo Manizola, cód.76, n. ${ }^{\circ} 6$.

21 Barata, A. F., Catacumbas, Tipografia Minerva, Évora (1883).

22 Manuscript, Biblioteca Pública de Évora, Évora, cód. CXXVIII/1-3, fls. 25-26.

23 'Notas de Gil Solteiro', manuscript, Arquivo Distrital de Évora, Évora, 1. ${ }^{\circ}$ 571, fls. 26-29.

24 'Livro dos acordos (1608-1611)', manuscript, Arquivo do Cabido da Sé de Évora, Évora, CEC 13-XV, fl. 46v.
25 'Livro de receitas e despesas da fábrica da Sé de Évora de 1660', manuscript, Arquivo do Cabido da Sé de Évora, Évora, fl. 34v.

26 'Livro de receitas e despesas da fábrica da Sé de Évora de 1680-1681', manuscript, Arquivo do Cabido da Sé de Évora, Évora, fl. 38v.

27 'Livro de receitas e despesas da fábrica da Sé de Évora de 1686-1687', manuscript, Arquivo do Cabido da Sé de Évora, Évora, fl. 37v.

28 'Livro de receitas e despesas da fábrica da Sé de Évora de 1687-1688', manuscript, Arquivo do Cabido da Sé de Évora, Évora, fl. 37v.

29 Manuscript, Biblioteca Pública de Évora, Évora, códice CVI/I- 27, fl. 22.

30 Sarantopoulos, P., 'Memória da vida e morte do $10 .^{\circ}$ Arcebispo de Évora D. Frei Luís da Silva Teles', A Cidade de Évora 43-44(69-70) (1986-87) 150.

31 Espanca, T., 'Memória da vida e morte do $10 .^{\circ}$ Arcebispo de Évora, D. Frei Luís da Silva Teles', A Cidade de Évora, Évora, 43-44(69-70) (1986-87) 125-179.

32 Paiva, J. P., 'D. Fr. Luís da Silva e a gestão dos bens de uma mitra. O caso da diocese de Lamego (1677-85)', in Estudos em Homenagem a João Francisco Marques, ed. L. A. O. Ramos and J. M. R. Amélia, Faculdade de Letras da Universidade do Porto, Porto (2001) 243-255, http://ler. letras.up.pt/uploads/ficheiros/2873.pdf (accessed 2008-0607).

33 Manuscript, Arquivo do Cabido da Sé de Évora, Évora, pasta 19, doc.73.

34 Manuscript, Arquivo do Cabido da Sé de Évora, Évora, pasta 19 , doc.75.

35 'Livro de receitas e despesas da fábrica da Sé de Évora de 1745-1746', manuscript, Arquivo do Cabido da Sé de Évora, Évora, fl. $41 \mathrm{v}$.

36 'Livro de receitas e despesas da fábrica da Sé de Évora de 1747-1748', manuscript, Arquivo do Cabido da Sé de Évora, Évora, fl. 44v.

37 'Livro de receitas e despesas da fábrica da Sé de Évora de 1748-1749', manuscript, Arquivo do Cabido da Sé de Évora, Évora, fl. 48v.

38 'Livro de receitas e despesas da fábrica da Sé de Évora de 1754-1755', manuscript, Arquivo do Cabido da Sé de Évora, Évora, fl. 45.

39 'Livro de receitas e despesas da fábrica da Sé de Évora de 1760-1761', manuscript, Arquivo do Cabido da Sé de Évora, Évora, fls. 22-22 v.

40 'Livro de receitas e despesas da fábrica da Sé de Évora de 1777-1778', manuscript, Arquivo do Cabido da Sé de Évora, Évora, fl. 62.

41 'Notas de Manuel Galvão', manuscript, Arquivo Distrital de Évora, Évora, $1 .^{\circ} 331$, fls. 40-42 v.

42 'L. $1^{\circ}$ dos Acórdãos', manuscript, Arquivo da Misericórdia de Mora, Mora, fls. 64-66.

43 Espanca, T., 'José de Escobar, pintor quinhentista. O retábulo da Misericórdoa de Mora', A Cidade de Évora 1415(39-40) (1957-58) 135-138.

44 Correia, J. L., A Santa Casa de Misericórdia de Mora, Mora (1964).

45 'Notas de Manuel Rodrigues', manuscript, Arquivo Distrital de Évora, Évora, $1 .^{\circ} 391$, fls. 20-21.

46 Serrão, V, O Maneirismo e o Estatuto Social dos Pintores Portugueses, INCM, Lisboa, (1983).

47 'Notas de Manuel Rodrigues', manuscript, Arquivo Distrital de Évora, Évora, 1. ${ }^{\circ} 391$, fls. 91-92

48 'Notas de Manuel Rodrigues', manuscript, Arquivo Distrital de Évora, Évora, 1. ${ }^{\circ} 402$, fls. 71 v-73. 
49 'Notas de Manuel Rodrigues', manuscript, Arquivo Distrital de Évora, Évora, $1 .^{\circ} 407$, fls. 84v-85v.

50 Manuscript, Biblioteca Pública de Évora, Évora, Cód. CXXX/1-10.

51 Fialho, M., 'Évora ilustrada. Com noticias, não já profanas mas sagradas, ou pertencentes ao sagrado', manuscript, Biblioteca Pública de Évora, Évora, vol. 3, fls. 497-498.

52 'Notas de Domingos Pires', manuscript, Arquivo Distrital de Évora, Évora, 1. ${ }^{\circ}$ 178, fls. 126-127.

53 'Livro 10 de acordos da Câmara Municipal (1604-1605)', manuscript, Arquivo Distrital de Évora, Évora, fl. 133v.

54 'Livro das lembranças (1587-1591)', manuscript, Arquivo do Cabido da Sé de Évora, Évora, CEC 13-X, fl. 81v.

55 'Livro de registo de alvarás do Cabido da Sé de Évora (15661598)', manuscript, Arquivo do Cabido da Sé de Évora, Evora, fl. 36v.

56 'Visitação dos Oratórịos de Évora de 1591', manuscript, Biblioteca Pública de Évora, Évora, cód. 61, fl. 127-128.

57 'Livro das lembranças (1591-1597)', manuscript, Arquivo do Cabido da Sé de Evora, Evora, CEC 13-XI, fl. 13v.

58 'Livro 29 dos acordos (1652-1663)', manuscript, Arquivo do Cabido da Sé de Évora, Évora, CEC 14-I, , fl. 197.

59 'Évoramonte - Alvará do Cabido', manuscript, Arquivo do Cabido da Sé de Évora, Évora, pasta 8, doc. 26.

60 'Livro de receitas e despesas da fábrica da Sé de Évora de 1764-1765' manuscript, Arquivo do Cabido da Sé de Évora, Évora, fl. 29v.

61 'Escritura de ajuste e contrato quanto às obras que se estão fazendo na Matriz do Lavre', manuscript, Arquivo do Cabido da Sé de Évora, Évora, pasta 8, Lavre, doc.12, fl.1.

62 'Notas de Gil Solteiro', manuscript, Arquivo Distrital de Évora, Évora, 1. ${ }^{\circ}$ 571, fls. 26-29.
63 Manuscript, Arquivo Distrital de Évora, Évora, Câmara Eclesiástica, Ordens menores, proc. n. ${ }^{\circ} 648$, mç. $n^{\circ} 181$, fl. 14.

64 Serrão, V., 'Francisco Nunes Varela e as oficinas de pintura em Evora no século XVII', A Cidade de Evora 3 (19981999) 85-171.

65 Manuscript, Arquivo Distrital de Évora, Évora, cx. a 3, nº 79, fl. $47 \mathrm{v}$.

66 'Liuro das propriedades foreiras do Cabido', manuscript, Arquivo do Cabido da Sé de Évora, Évora, CEC 6-IV, fl. 148.

67 'Livro dos estatutos, aniuersários, foros, etc dos bachareis da Sé de Évora (séc.XVII)', manuscript, Arquivo do Cabido da Sé de Évora, Évora, CEC 4 -XIV, fls. 52, 88-88v.

68 Manuscript, Biblioteca Pública de Évora, Évora, Convento do Carmo, Livro n ${ }^{\circ} 6$, fls. 33-39.

Received: 2015-07-16

Revised: 2016-01-20

Accepted: 2016-01-21

Online: 2016-01-24

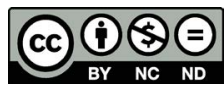

This work is licensed under the Creative Commons Attribution-NonCommercial-NoDerivatives 4.0 International License.

To view a copy of this license, visit http://creativecommons.org/licenses/by-nc-nd/4.0/deed.en. 